\title{
ANALISIS NERACA SUMBER DAYA PASIR BESI DAN BIJIH NIKEL INDONESIA
}

\author{
Resources Balance Analysis of Iron Sand and Nickel Ore in Indonesia
}

\author{
HARTA HARYADI \\ Puslitbang Teknologi Mineral dan Batubara \\ Jalan Jenderal Sudirman 623 Bandung 40211 \\ Telp. (022) 6030483, Fax. (022) 6003373 \\ e-mail: hartah@tekmira.esdm.go.id
}

\begin{abstract}
ABSTRAK
Sampai saat ini data dan informasi sumber daya pasir besi dan nikel Indonesia, serta perkiraan dan analisis keekonomiannya secara periodik belum dimiliki oleh para pemangku kepentingan. Validasi data sumber daya pasir besi dan nikel belum terdokumentasi dengan akurat karena belum ada koordinasi dan sinkronisasi antar instansi terkait yang menangani data sumber daya, khususnya bijih besi dan nikel. sehingga data dan informasi sumber daya mineral pasir besi dan nikel sangat beragam, berbeda-beda antar instansi atau lembaga, perusahaan maupun asosiasi-asosiasi pertambangan. Tulisan ini bertujuan untuk menganalisis neraca sumber daya pasir besi dan nikel di Indonesia. Dari hasil analisis diketahui nilai awal sumber daya pasir besi tahun 2015 sebesar 2,12 miliar ton, dieksploitasi sebesar 1,15 juta ton, penemuan hasil eksplorasi baru sebesar 2,33 miliar ton, saldo akhir menjadi 4,45 miliar ton, dengan harga sebesar US\$ 65 per ton, diperoleh nilai ekonomis bruto sumber daya pasir besi sebesar US\$289,83 miliar. Sumber daya nikel, awal tahun 2015 diketahui sebesar 3,71 miliar ton, dieskploitasi sebesar 3,50 juta ton, penemuan baru hasil eksplorasi sebesar 1,94 miliar ton dan saldo akhir sumber daya sebesar 5,65 miliar ton, dengan harga bijih nikel sebesar US\$29 maka nilai ekonomis sumber daya nikel sebesar US\$ 164,08 miliar. Hasil analisis diharapkan dapat memberi manfaat sebagai basis data dalam pengelolaan sumber daya pasir besi dan nikel.
\end{abstract}

Kata kunci : nilai ekonomis, neraca sumber daya, pasir besi, bijih nikel, kebijakan.

\begin{abstract}
To date, data and information on Indonesia iron and nickel sands, as well as their economic forecasts and analyzes periodically, are not owned by the stakeholders. Validation of iron and nickel iron resource data has not been accurately documented because there has been no coordination and synchronization between related agencies that handle resource data, particularly iron ore and nickel. As a result, the data and information of mineral resources of iron and nickel sand is very diverse, varies between agencies or institutions, companies and mining associations. This paper aims to analyze the balance of iron and nickel resources in Indonesia. From the analysis result, it is known that the value of iron sand resource in 2015 amounted to 2.12 billion tons, 1.15 million tons exploited, the discovery of new exploration result of 2.33 billion tons, the final balance to 4.45 billion tons, US \$ 65 per ton, obtained gross economic value of iron sand resource of US \$289.83 billion. Nickel resources at the beginning of 2015 are known at 3.71 billion tons, exploited 3.50 million tons, new invention of exploration results to 1.94 billion tons, and end resources balance of 5.65 billion tons, with the price of nickel ore equal to US \$29, then the economic value of nickel resources is US $\$ 164.08$ billion. The results of the analysis are expected to provide benefits as a database in the management of iron and nickel sands.
\end{abstract}

Keywords: economic value, balance resources, iron ore, nickel ore, policies. 


\section{PENDAHULUAN}

\section{Latar Belakang}

Indonesia memiliki sumber daya serta cadangan pasir besi dan bijih nikel yang sangat besar. Namun, sampai saat ini data dan informasi sumber daya serta perkiraan keekonomiannya secara periodik belum dimiliki. Validasi data sumber daya pasir besi dan nikel belum terdokumentasi dengan akurat karena belum ada koordinasi dan sinkronisasi antar instansi terkait yang menangani data sumber daya, khususnya bijih besi dan nikel. Selain itu, data dan informasi sumber daya belum mempunyai standar tertentu sebagai pegangan sehingga data dan informasi sumber daya mineral sangat beragam, berbeda-beda antar instansi atau lembaga, perusahaan maupun asosiasi-asosiasi pertambangan. Kondisi ini menyebabkan pemerintah sulit membuat kebijakan yang tepat terkait sumber daya mineral terkait.

Dari berbagai permasalahan yang terkait dengan sumber daya ini maka perlu disusun analisis neraca sumber daya pasir besi dan nikel. Dari hasil analisis neraca sumber daya tersebut, dapat diketahui besarnya volume sumber daya dan nilai ekonomis pasir besi dan nikel yang bisa menjadi basis data sumber daya bagi seluruh pemangku kepentingan. Dengan demikian diharapkan pemerintah bisa mengambil kebijakan terkait pengelolaan sumber daya pasir besi dan nikel yang dapat memberikan manfaat sebesar-besarnya bagi seluruh pemangku kepentingan. Di samping itu diharapkan pula hal-hal yang menghambat pengelolaan sumber daya pasir besi dan nikel dapat diperkecil.

Neraca sumber daya ini dapat digunakan oleh pemerintah daerah untuk mengatur pemanfaatannya bagi generasi mendatang, memanfaatkan sumber daya pasir besi dan nikel secara rasional, memperbaiki cara pengelolaan sumber daya tersebut dan dapat mengukur seberapa besar manfaat ekonomis yang dapat diperoleh dari aktiva atau aset sumber daya pasir besi dan nikel yang dimilikinya.

Tulisan ini bertujuan untuk menganalisis neraca sumber daya pasir besi dan nikel di Indonesia.

\section{METODE}

Pengumpulan data dilakukan melalui inventarisasi data dari setiap instansi pemerintah atau perusahaan yang menanganinya dalam kurun waktu 20112015, meliputi:

1. Data sumber daya pasir besi dan nikel nasional dari Pusat Sumber Daya Geologi;

2. Data sumber daya dan produksi pasir besi dan nikel pada periode tahun yang sedang berjalan dari Dinas Pertambangan Kalimantan Barat dan Maluku Utara serta Pusat Sumber Daya Geologi;

3. Produksi tahunan pasir besi dan nikel nasional dari Direktorat Jenderal Mineral dan Batubara;

4. Harga pasir besi dan nikel terbaru yang berlaku di pasaran dari Direktorat Jenderal Mineral dan Batubara.

Metode analisis dilakukan melalui beberapa tahapan, yang mengacu kepada SNI No. 196728.4-2002-ICS No. 13.060.10 (Badan Standardisasi Nasional, 2015), yaitu :

1. Neraca sumber daya pasir besi dan nikel dari tahun $X$ hingga tahun $X$, dibuat mengacu pada Petunjuk Teknis Penyusunan Neraca Sumber Daya Alam Bagian Ke-4 : Sumber Daya dan Cadangan Mineral dan Batubara.

2. Untuk menjelaskan neraca sumberdaya dan cadangan pasir besi dan nikel di atas, selanjutnya diambil tahun $\mathrm{X}$ lalu disusun dalam bentuk tabel scontro yang berisi pasiva dan aktiva.

3. Dari perhitungan aktiva dan pasiva akan menghasilkan saldo akhir sumberdaya pasir besi dan nikel.

4. Selanjutnya dari saldo sumber daya akhir akan diperolah nilai ekonomis sumber daya akhir, berupa sumber daya akhir dikalikan dengan harga yang berlaku setiap periode tahun berjalan.

\section{Kolom Aktiva}

1. Pada kolom aktiva ini mencatat sub total sumber daya awal, baik dalam satuan ton maupun dalam satuan nilai uang (Artha dkk., 2014). Sumber daya awal ini merupakan total dari sumber daya terukur, terindikasi, tereka, hipotetik, yang 
didapatkan dari data dalam tabel inventarisasi sumber daya mineral;

2. Dari sub total sumber daya awal, selanjutnya dijumlahkan dengan total pertambahan sumber daya, meliputi penemuan sumber daya baru, pertumbuhan alamiah, dan adanya pengalihan sumber daya lain akan diperoleh total sumber daya akhir. Selain itu dimungkinkan ada perbaikan perhitungan sumber daya dalam inventarisasi atau perhitungan di luar klasifikasi di atas, tetapi masih dalam perhitungan aktiva (Sallata, 2015).

3. Dari total aktiva sumber daya akhir selanjutnya dikalikan dengan harga terbaru yang berlaku setiap periode maka diperoleh nilai ekonomis.

\section{Kolom Pasiva}

1. Pada kolom pasiva ini mencatat pemanfaatan atau penyusutan atau eksploitasi sumber daya pasir besi dan bijih nikel baik dalam satuan ton maupun dalam nilai uang (Artha dkk., 2014). Pemanfaatan sumberdaya pasir besi dan bijih nikel mencakup penyusutan dan faktor eksternalitas, akibat dieksploitasi/ produksi, terjadinya bencana alam atau dipindahkan ke sumber daya lain yang akan menyebabkan berkurangnya sumber daya.

2. Faktor eksternalitas : misalnya kerusakan lingkungan hidup pada saat eksplorasi, semuanya harus diperhitungkan karena ada kaitannya dengan pemanfaatan sumberdaya (Jacob, 2013).

3. Perhitungan total pasiva, merupakan hasil pengurangan total kolom aktiva dikurangi jumlah pemanfaatan/penyusutan/produksi kolom pasiva, baik dalam bentuk ton maupun dalam bentuk nilai uang, sehingga diperoleh saldo akhir. Saldo akhir,merupakan hasil akhir tahun takwim dari total aktiva dikurangi total pasiva.

4. Setelah itu, saldo akhir ini dikalikan dengan harga pasir besi maupun bijih nikel sesuai harga tahun berjalan komoditi tersebut dan seluruhnya dikonversikan ke dalam nilai uang (US\$ atau dalam bentuk rupiah), setelah dikalikan dengan harga.

5. Seluruh metode pengumpulan data dan metode analisis neraca sumber daya pasir besi dan neraca sumber daya bijih nikel untuk kurun waktu 2011-2015 ditampilkan dalam bentuk neraca scontro seperti dalam Tabel 1, sedangkan untuk menghitung dalam satu tahun ditampilkan dalam Tabel 2.

6. Neraca model scontro apabila diaplikasikan dalam neraca sumber daya mineral pasir besi dan nikel dapat disajikan sebagai berikut : sumber daya awal - Produksi + penemuan sumber daya baru = sumber daya akhir. Nilai ekonomis sumber daya akhir diperoleh setelah dikalikan dengan harga yang berlaku pada tahun berjalan (Setiawan dkk., 2014).

Tabel 1. Neraca sumber daya mineral biijih besi dan bijih nikel tahun $\mathrm{x}-\operatorname{tahun} \mathrm{x}$

\begin{tabular}{cl}
\hline No. & \multicolumn{1}{c}{ Perincian } \\
\hline 1. & Sumber Daya Awal \\
2. & $\begin{array}{l}\text { Pertambahan Sumber Daya Baru } \\
\text { Penemuan sumber daya baru } \\
\text { Pertumbuhan alamiah }\end{array}$ \\
& $\begin{array}{l}\text { Pengalihan dari sumber daya lain } \\
\text { 3. }\end{array}$ \\
& $\begin{array}{l}\text { Penyusutan (Deplesi) } \\
\text { Produksi }\end{array}$ \\
& Bencana alam \\
4. & Pengalihan ke sumber lain \\
5. & Sumber Dayan Akhir \\
6. & Harga Mineral Pasir besi\& Nikel Per Ton \\
7. & Nilai Ekonomis Sumber Daya Pasir besi\& Nikel \\
\hline
\end{tabular}


Tabel 2. Neraca sumber daya nikel untuk tahun $\mathrm{x}$

\begin{tabular}{|c|c|c|c|c|c|c|}
\hline \multicolumn{3}{|l|}{ Aktiva } & \multicolumn{4}{|c|}{ Pasiva } \\
\hline \multirow{2}{*}{ Sumber Daya } & \multicolumn{2}{|c|}{ Satuan } & \multirow{2}{*}{ Eksploitasi } & \multirow{2}{*}{$\mathrm{Ha} / \mathrm{M}^{3}$} & \multicolumn{2}{|c|}{ Satuan } \\
\hline & Ton & US\$ & & & Ton & US\$ \\
\hline Sumber Daya Awal & & & Pemanfaatan/ Penyutan & & & \\
\hline Terkira & & & 1. Produksi & & & \\
\hline Terindikasi & & & 2. Bencana & & & \\
\hline Tereka & & & 3. Pengalihan ke sumber lain & & & \\
\hline \multicolumn{7}{|l|}{ Hipotetik } \\
\hline Sub Total & & & Sub Total & & & \\
\hline Pertambahan Sumber Daya & & & Faktor Eksternalitas & & & \\
\hline Terkira & & & 1. Biaya kerusakan lingkungan & & & \\
\hline Terindikasi & & & saat eksploitasi & & & \\
\hline Tereka & & & 2. Lain-lain & & & \\
\hline \multicolumn{7}{|l|}{ Hipotetik } \\
\hline Sub Total & & & Sub Total & & & \\
\hline \multicolumn{7}{|l|}{ Harga bijih nikel US\$29/ton } \\
\hline Total & & & Total & & & \\
\hline Saldo Akhir & & & & & & \\
\hline
\end{tabular}

\section{Kajian Teoritis}

Sumberdaya alam yang besar yang dimiliki Indonesia merupakan salah satu modal bangsa yang perlu dikembangkan dan dioptimalkan untuk menunjang dan mendukung pembangunan nasional yang berkelanjutan (Solihin dan Sudirja, 2007). Oleh sebab itu menurut Putra dkk. (2015), pemanfaatan sumber daya alam tersebut harus memperhatikan konservasi dan upaya untuk kelestarian fungsi ekosistemnya. Untuk mendukung keberhasilan usaha tersebut menurut Muliawan dkk. (2009), lokasi keterdapatan, potensi dan kondisi sumber daya alam yang dimiliki yang ada di setiap wilayah, harus disusun dalam bentuk neraca sumber daya alam (NSDA). NSDA terdiri dari empat komponen, yaitu neraca sumber daya lahan (NSDL), neraca sumber daya hutan $(\mathrm{NSDH})$, neraca sumber daya air (NSA), dan neraca sumber daya mineral (NSDM).

Neraca sumber daya mineral (NSDM), merupakan neraca yang terkait dengan sektor pertambangan mineral (Badan Standardisasi Nasional, 2015). Dalam NSDM terdapat informasi mengenai besarnya sumber daya, jumlah yang telah dimanfaatkan (diproduksi) dan cadangan yang masih tersisa (saldo) serta penemuan sumber daya baru karena adanya eksplorasi baru yang akan menambah jumlah sumber daya akhir, yang kesemuanya dapat dikonversikan dalam nilai uang sesuai harga terbaru yang berlaku dari waktu ke waktu.
Dalam neraca sumber daya mineral menurut Prasadewo dkk. (2016), ada suatu bagian dari laporan keuangan (nilai ekonomis sumber daya) yang bisa menjadi dasar dalam menghasilkan keputusan bisnis. Menurut Jarwanto (2008), struktur neraca terdiri atas dua pos yaitu aktiva (aset) dan pasiva (pemanfaatan /eksploitasi). Menurut (Tivianto dkk. (2013), pada pos aktiva (tercatat sumber daya awal yang merupakan total dari sumber daya terkira, terindikasi, tereka dan hipotetik selanjutnya ditambah dengan sumber daya hasil eksplorasi terbaru) dan pada pos pasiva (tercatat pemanfaatan yang akan mengurangi jumlah sumber daya yang terdiri atas produksi, bencana, pengalihan ke sumber lain dan biaya kerusakan lingkungan).

Menurut (Nurfatriani, 2006), aktiva dapat dianggap sebagai sumber daya, sedangkan pasiva berupa kewajiban dianggap sebagai produksi dan equitas atau modal dianggap sebagai eksplorasi sumber daya baru. Jadi prinsipnya menjadi sumber daya akhir = sumber daya awal - Produksi + eksplorasi sumber daya baru. Dari sumber daya akhir ini bisa dihitung nilai ekonomisnya dengan mengalikan jumlah sumber daya dengan harga pada periode tahun bersangkutan. Bentuk neraca sumber daya pasir besi dan nikel ada yang dalam bentuk stafel (memanjang ke bawah) dan bentuk menyamping (skontro). Bentuk Skontro sangat cocok dan mudah untuk diterapkan apabila 
akun dan juga nilai yang ada pada perusahaan jumlahnya sedikit (Anna dkk., 2016).

Sumber daya alam yang dimiliki Indonesia menurut Jumari $d k k$, (2013), khususnya sektor mineral, nilai ekonomisnya sangat besar apabila dinilai dengan uang. Selain itu terdapat potensi ekonomi yang luar biasa besar dari mineral jarang yang sampai saat ini belum diolah secara ekonomis seperti skandium, lantanum dan ytrium pada bijih nikel dan vanadium serta titanium pada pasir besi (Arief dkk., 2011).

Sampai saat ini, permasalahan yang timbul dari pembuatan neraca sumber daya mineral adalah belum dilakukan secara komprehensif dari seluruh pemangku kepentingan (Guswakhid, 2013), sehingga hasilnya belum dapat dijadikan kebijakan yang tepat oleh pemerintah, untuk mengelola sumber daya mineral yang dapat menguntungkan seluruh pemangku kepentingan.

\section{HASIL DAN PEMBAHASAN}

Berdasarkan Pusat Sumber Daya Geologi (2016), pada tahun 2011 Indonesia memiliki sumber daya pasir besi sebesar 1,59 miliar ton dan sumber daya nikel sebesar 2,88 miliar ton. Pada tahun 2015 jumlah sumber daya pasir besi dan nikel yang yang dimiliki semakin besar, antara lain pasir besi dengan sumber daya bijih sebesar 4,45 miliar ton dan cadangan bijih sebesar 808,93 juta ton, sedangkan sumber daya nikel berjumlah 5,65 miliar ton dan cadangan bijih sebesar 3,19 miliar ton. Pertambahan sumber daya pasir besi dan nikel ini disebabkan setiap tahunnya ada penemuan sumber daya baru karena dilakukannya kegiatan-kegiatan eksplorasi (Tabel 6 dan Tabel 7). Jumlah sumber daya yang sangat besar ini, sampai saat ini data dan informasi perkiraan keekonomiannya secara periodik belum dimiliki, validasi data belum terdokumentasi, data sumber daya belum terintegrasi dan belum ada koordinasi maupun sinkronisasi dengan instansi terkait yang juga menangani data sumber daya. Selain itu, data dan informasi sumber daya belum terstandarisasi, sehingga datanya berbeda-beda baik yang dikeluarkan Dinas Pertambangan, Pusat Sumber Daya Geologi, BPS, Ditjen Mineral dan Batubara, Kementerian
Perindustrian, Kementerian Perdagangan maupun dari Pusdatin Kementerian ESDM.

Dari uraian Tabel 6 Neraca Sumber Daya Pasir Besi, dapat diketahui sumber daya awal pasir besi pada tahun 2011 sebesar 1,59 miliar ton, dieksploitasi atau diproduksi sebesar 13,10 juta ton dan sumber daya akhir sebesar 1,58 miliar ton. Pada tahun 2011, harga bijih pasir besi sebesar US\$25,20 per ton sehingga nilai ekonomis sumber daya akhir yang merupakan aktiva atau aset sebesar US\$ 39,91 miliar. Pada tahun 2015, ditemukan sumber daya pasir besi baru yang sangat besar 2,33 miliar ton karena ada kegiatan-kegiatan eksplorasi dan dieksploitasi sebesar 1,15 juta ton dengan harga pasir besi sebesar US\$ 65 per ton, sehingga nilai akhir sumber daya pasir besi menjadi 4,45 miliar ton dengan nilai ekonomis sebesar US\$ 289,83 miliar.

Dari uraian Tabel 7 Neraca Sumber Daya Nikel, diketahui sumber daya awal nikel pada tahun 2011 sebesar 2,88 miliar ton dieksploitasi atau diproduksi sebesar 32,90 juta ton dan sumber daya akhir sebesar 2,84 miliar ton. Pada tahun 2011, harga bijih nikel sebesar US\$76,00 per ton sehingga nilai ekonomis sumber daya akhir yang merupakan aktiva atau aset sebesar US\$216,53 miliar. Pada tahun 2015, ditemukan sumber daya bijih nikel baru yang sangat besar 1,94 miliar ton karena adanya kegiatan-kegiatan eksplorasi yang dilakukan dan dieksploitasi sebesar 3,50 juta ton dengan harga bijih nikel sebesar US\$29,00 per ton, sehingga nilai akhir sumber daya bijih nikel menjadi 5,65 miliar ton dengan nilai ekonomis sebesar US\$ 164,08 miliar.

Dari neraca sumber daya pasir besi dan nikel ini dapat diketahui pada tahun 2015 sumber daya pasir besi sangat besar mencapai 4,45 miliar ton (nilai ekonomisnya dengan harga per ton sebesar US\$ 65 diperoleh sebesar US\$ 289,83 miliar) dan sumber daya nikel yang mencapai 5,65 miliar ton (nilai ekonomisnya dengan harga per ton sebesar US\$ 28 diperoleh sebesar US\$164,08 miliar).

Meski sumber daya pasir besi dan nikel yang dimiliki Indonesia sangat besar, namun sampai saat ini pengelolaannya belum optimal sehingga belum memberikan manfaat yang 
signifikan (Soepriadi dkk., 2013). Dari hasil survei tahun 2016, masih banyak industri logam yang membutuhkan bahan baku dari olahan pasir besi dan nikel masih impor karena kesulitan mendapatkan bahan baku dari dalam negeri. Di samping itu, pajak dan royalti yang diperoleh dari mineral tersebut belum sifnifikan sehingga belum memberikan manfaat ekonomi yang besar bagi daerah yang memiliki sumber daya pasir besi dan nikel yang besar seperti Provinsi Kalimantan Selatan, Sulawesi Tenggara dan Maluku Utara. Sampai saat ini, kebijakan hilirisasi dan kewajiban peningkatan nilai tambah pasir besi dan nikel sebagaimana diamanatkan UndangUndang no. 4 tahun 2009 tentang mineral dan batubara yang mewajibkan seluruh pemegang IUP mineral pasir besi dan nikel masih berjalan di tempat, walaupun kebijakan tersebut sudah digulirkan 8 tahun lebih.

Selain itu, jumlah sumber daya pasir besi dan nikel yang besar ini tidak menjadi daya tarik bagi perusahaan untuk membangun pabrik pengolahan dan pemurnian logam besi dan logam nikel, terbukti sampai tahun 2016 hanya ada 12 perusahaan yang mengolah nikel itupun hanya sampai nickel pig iron, nikel matte dan ferronikel (PT. Vale, PT. Antam, PT. Fajar Bhakti, PT. Sulawesi Mining, PT. Gebe Industry, Indoferro, Century Metalido, Indonesia Guang Ching, PT. Cahaya Modern Metal Industri, PT. Macika Mineral Industri, Bintang Timur, dan Titan Mineral). Sedangkan yang mengolah pasir besi hanya ada 2 perusahaan, itupun sampai kepada komoditi pig iron (PT. Jogja Mangasa Iron dan PT. Sumber Baja Prima).

Dengan adannya neraca sumber daya pasir besi dan nikel sehingga diketahui sumber daya akhir pasir besi dan bijih nikel serta diketahuinya nilai ekonomis dari sumber daya akhir yang sangat besar, maka pemerintah dapat membuat kebijakan untuk mengatur dan mendayagunakan manfaat sumber daya mineral tersebut lebih optimal baik untuk mendukung perusahaan smelter besi dan nikel (kebijakan hilirisasi) maupun untuk menunjang dan mendukung pembangunan nasional yang berkelanjutan, serta dapat melakukan konservasi dan kelestarian fungsi ekosistemnya, yang terkait dengan pemanfaatan pasir besi dan bijih nikel. Manfaat neraca sumber daya pasir besi dan nikel ini akan lebih optimal bila dilakukan secara periodik, analisisnya lebih menyeluruh, validasi ekonominya dilakukan lebih detil, diintegrasikan serta disinkronisasikan dan dikoordinasikan dengan seluruh pemangku kepentingan yang terkait dengan sumber daya.

\section{Sumber Daya Pasir besi}

Secara geologis, cebakan besi di Indonesia terdiri atas empat jenis endapan, antara lain pasir besi, besi laterit atau bijih besi, besi primer dan besi sedimen. Struktur geologi yang kompleks yang dimiliki Indonesia menjadikan Indonesia kaya akan sumber daya energi dan mineral, yang salah satunya mineral besi (Dinas Pertambangan dan Energi Provinsi Kalimantan Selatan, 2015). Sumber daya dan cadangan besi yang dimiliki Indonesia cukup besar, tersebar di beberapa propinsi, antara lain Propinsi Aceh, Provinsi Sumatera Barat, Provinsi Bangka Belitung, Provinsi Kalimantan Barat, Provinsi Kalimantan Selatan dan Provinsi Sulawesi Barat.

Berdasarkan data dari Pusat Sumber Daya Geologi (2016), pada tahun 2015 jumlah sumber daya besi laterit sebesar 2,44 miliar ton (bijih) dan 894,99 juta ton (logam), sedangkan cadangannya berjumlah 542,51 juta ton (bijih) dan 154,31 juta ton (logam). Besi laterit tersebar diLampung, Jawa Barat, Kalimantan Selatan, Sulawesi Selatan, Sulawesi Tenggara, Maluku Utara, Irian Jaya Barat, Papua Barat, dan Papua. Di samping besi laterit, terdapat juga sumber dayapasir besi, besi primer, dan besi sedimen. Sumber daya pasir besi jumlahnya lebih besar dibanding besi laterit dengan jumlah sebesar 4,45 miliar ton (bijih) dan 1,68 miliar ton (logam), sedangkan cadangannya berjumlah sebesar(bijih) 808,93 juta ton dan (logam) 397,33 juta ton (Tabel 3).

Jumlah sumber daya besi primer berjumlah 1,39 miliar ton (bijih) dan 418,88 juta ton (logam) dan cadangan sebesar 279,35 juta ton (bijih) dan 97,55 juta ton (logam). Penyebaran pasir besi dan besi primer antara lain di Aceh, Bengkulu, Lampung, Jawa Barat, Jawa Tengah, DI Yogyakarta, Jawa Timur, Nusa Tenggara Barat, Nusa Tenggara Timur, Sulawesi Selatan, Sulawesi Barat, Sulawesi Tengah, Sulawesi 
Utara, Maluku Utara, dan Papua. Adapun sumber daya besi sedimen berjumlah 18,64 juta ton (bijih) dan sebesar 11,75 juta ton (logam) yang sebagian besar keberadaannya terdapat di Provinsi Jawa Timur. Untuk cadangan besi sedimen sampai saat ini belum diketahui, disebabkan belum dilakukan eksplorasi lanjutan sampai analisis keekonomian untuk sumber daya tersebut.

Berdasarkan Pusat Sumber Daya Geologi (2016), khususnya untuk sumber daya pasir besi terus mengalami peningkatan. Pada tahun 2011 sumber daya berjumlah sebesar 1,58 miliar ton, pada tahun 2012 menurun sedikit menjadi 1,53 miliar ton karena adanya produksi yang meningkat pesat namun pada tahun 2013 meningkat kembali menjadi 2,11 miliar ton disebabkan adanya penemuan sumber daya baru yang sangat besar mencapai 608,76 juta ton, dan pada tahun 2014 meningkat kembali menjadi 2,12 miliar ton karena adanya penemuan sumber daya baru sebesar 11,00 juta ton dan pada tahun 2015 sumber daya meningkat sangat besar sekali menjadi 4,46 miliar ton karena adanya penemuan sumber daya yang baru lagi sebesar 2,33 miliar ton (Gambar 1).

\section{Industri Pengguna Pasir Besi}

Industri pemakai pasir besi pada umumnya adalah industri besi baja, dari industri besi baja dikonsumsi oleh industri baja Lembaran (canai panas) yang digunakan oleh industri galangan kapal, kontainer, pipa dan tabung, Industri otomotif, gerbong kereta api, industri konstruksi, tangki, tiang. Baja lembaran (canai dingin) yang digunakan oleh industri seng, industri karoseri, drum, pipa, alat-alat listrik, pengepakan, alat-alat rumah tangga, mebel dari besi, kaleng dan kemasan. batang (kawat) yang digunakan oleh industri mur dan baut, sekerup, paku, per, kawat baja, kawat bronjong, kawat las. serta baja tulangan, yang dipakai untuk industri konstruksi, gedung, jembatan, dermaga, gudang, crane, dan tiang dari besi.

\section{Produksi Pasir Besi}

Menurut data dari Ditjen Minerba 2016, dalam kurun waktu 2011 - 2015 produksi pasir besi nasional meningkat secara fluktuatif. Pada tahun 2011, produksi pasir besi Indonesia sebesar 13,10 juta ton dan ekspor sebesar 14,01 juta ton dan pada tahun 2013 terjadi lonjakan produksi yang sangat besar hingga mencapai 19,00 juta ton dan ekspor sebesar 22,30 juta ton. Besarnya produksi dan ekspor pasir besi pada tahun 2013, disebabkan pada tahun 2014 sesuai UU No. 4/2009, seluruh perusahaan tidak boleh mengekspor mineral dalam bentuk bijih. Dari kondisi ini dapat dilihat, bahwa hampir semua perusahaan pemegang IUP pasir besi di Indonesia, selama kurun waktu 5 tahun diberi kesempatan hingga tahun 2014 untuk mempersiapkan pabrik pengolahan dan pemurnian tidak dilakukan, yang terjadi adalah mayoritas menambang pasir besi secara besar-besaran sebelum berlakunya UU No. 4 tersebut.

Pada tahun 2014 ketika diberlakukannya UU No. 4/2009, hampir seluruh pemegang IUP pasir besi belum siap untuk mengolah dan memurnikan pasir besi, dengan alasan kadar besi yang terkandung dari hasil produksi pasir besi tidak sesuai dengan kadar yang diminta oleh industri pengolahan dan pemurnian pasir besi di dalam negeri. Diberikan kesempatan kembali kepada para pemegang IIUP pasir besi hingga waktu tahun 2017 untuk benarbenar mendirikan pabrik pengolahan dan pemurnian pasir besi di dalam negeri, sehingga terjadi lagi ekspor pasir besi pada tahun 2014 sebesar 3,16 juta ton dari produksi sebesar 7,00 juta ton, dan pada tahun 2015 ekspor sebesar 3,12 juta ton dari produksi sebesar 1,15 juta ton.

Apabila melihat data kondisi pemasokan dan kebutuhan pasir besi Indonesia selama kurun waktu tahun 2011 - 2015, maka terlihat ketidak sesuaian data jumlah produksi dengan jumlah yang diekspor (Tabel 4). Apabila melihat kondisi data seperti ini, ada beberapa kemungkinan yang terjadi :

- Tidak semua perusahaan pemegang IUP Operasi Produksi pasir besi, melaporkan jumlah produksi pasir besinya.

- Ada beberapa pelabuhan ekspor yang selama ini tidak terpantau oleh dinas terkait. 
Tabel 3. Sumber daya dan cadangan pasir besi dan nikel Indonesia

\begin{tabular}{llrrrr}
\hline \multirow{2}{*}{ No. } & \multirow{2}{*}{ Komoditi } & \multicolumn{2}{c}{ Sumber Daya } & \multicolumn{2}{c}{ Cadangan } \\
\cline { 3 - 6 } & & \multicolumn{1}{c}{ Bijih } & \multicolumn{1}{c}{ Logam } & Bijih & \multicolumn{1}{c}{ Logam } \\
\hline 1. & Besi Laterit & 2.440 .455 .194 & 894.995 .636 & 542.514 .188 & 154.307 .553 \\
2. & Besi Primer & 1.397 .068 .930 & 418.888 .703 & 279.354 .825 & 97.555 .769 \\
& (Pasir besi) & & & & \\
3. & Pasir Besi & 4.459 .586 .351 & 1.683 .084 .164 & 808.938 .227 & 397.334 .700 \\
4. & Besi Sedimen & 18.643 .723 & 11.747 .136 & & - \\
\hline & Total Besi & 8.315 .754 .198 & 3.008 .715 .639 & 1.630 .807 .240 & 649.198 .022 \\
\hline 5. & Nikel & 5.656 .362 .683 & 79.172 .702 & 3.197 .178 .940 & 50.872 .304 \\
\hline
\end{tabular}

Sumber : Pusat Sumber Daya Geologi (2016)

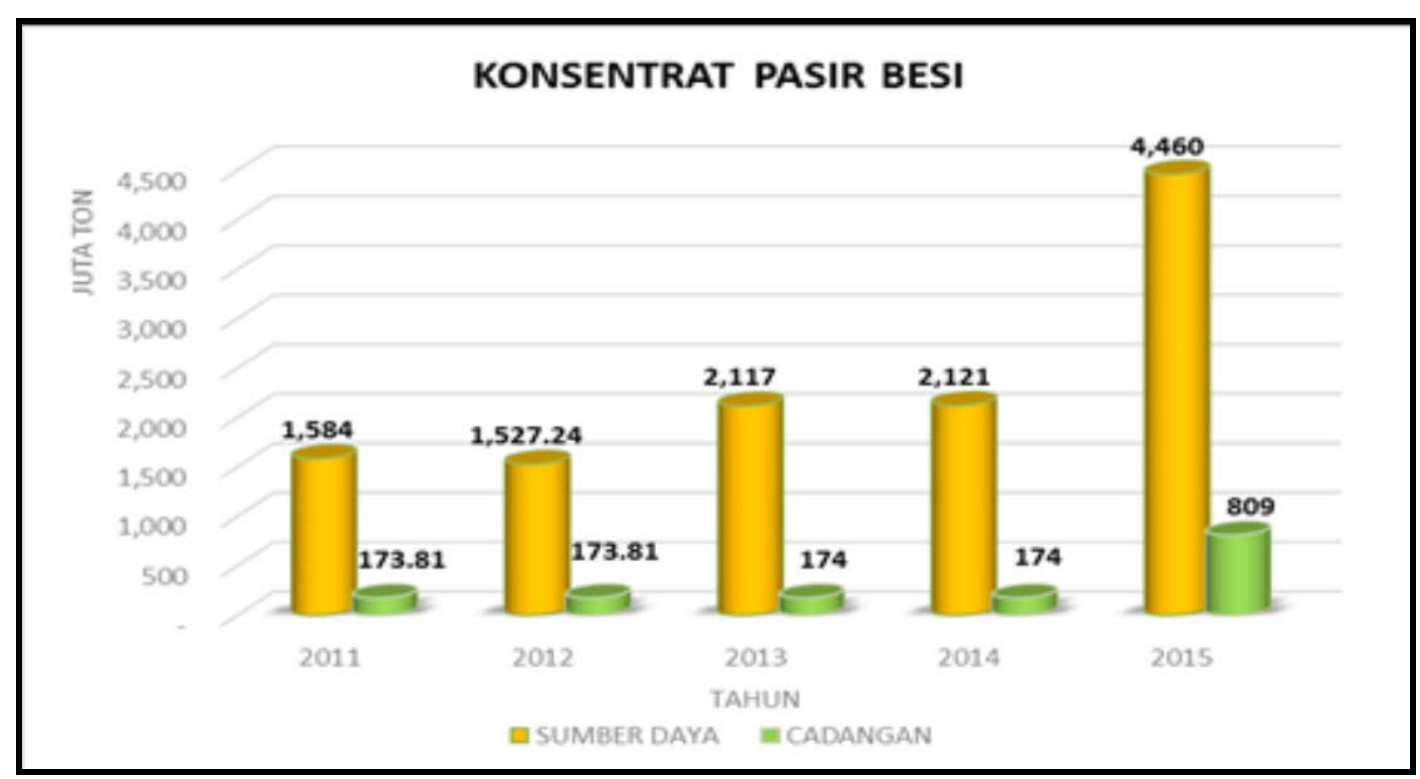

Sumber : Pusat Sumber Daya Geologi (2016)

Gambar 1. Total sumber daya pasir besi tahun 2011 - 2015

Tabel 4. Kondisi pemasokan dan kebutuhan pasir besi Indonesia

\begin{tabular}{ccccr}
\hline Tahun & $\begin{array}{c}\text { Produksi } \\
\text { (ton) }\end{array}$ & $\begin{array}{c}\text { Konsumsi } \\
\text { (ton) }\end{array}$ & $\begin{array}{c}\text { Ekspor } \\
\text { (ton) }\end{array}$ & \multicolumn{1}{c}{$\begin{array}{c}\text { Impor } \\
\text { (ton) }\end{array}$} \\
\hline 2011 & 13.100 .000 & 2.141 .001 & 14.013 .744 & 1.804 .945 \\
2012 & 10.000 .000 & 1.986 .501 & 11.545 .752 & 974.611 \\
2013 & 19.000 .000 & 2.216 .300 & 22.308 .220 & 1.933 .250 \\
2014 & 7.000 .000 & 2.817 .223 & 3.162 .404 & 3.871 .537 \\
2015 & 1.150 .000 & 3.001 .242 & 3.129 .713 & 5.424 .821 \\
\hline
\end{tabular}

Sumber : Ditjen Minerba, Subdit Pengawasan Usaha Produksi Mineral (2016) Kementerian Perdagangan ( 2016) dan Badan Pusat Statistik (2016)

Konsumsi olahan pasir besi di Indonesia dapat dibedakan menjadi dua golongan berdasarkan industri pemakainya, yakni industri besi baja dan kelompok industri lain. Pada golongan industri lain, pemakai terbesar pasir besi adalah industri semen. Pasir besi produksi dalam negeri tidak memenuhi syarat untuk industri besi baja sehingga bahan baku yang digunakan sepenuhnya berasal dari impor. Sementara itu untuk penggunaan dalam negeri, seluruh pasir besi produksi lokal dijual ke industri semen.

Perkembangan konsumsi pasir besi dapat dilihat berdasarkan perkembangan angka 
penjualan pasir besi terhadap industri semen di dalam negeri. Total konsumsi pasir besi dalam negeri selama kurun waktu 2011-2015 hampir sama dengan tingkat produksinya, yaitu terus meningkat. Pada tahun 2011 total konsumsinya mencapai 2,14 juta ton. Tahun 2012 konsumsinya menurun mencapai 1,99 juta ton, tetapi tahun-tahun berikutnya kembali meningkat hingga mencapai 3,00 juta ton pada tahun 2015.

\section{Sumber Daya Nikel}

Bersasarkan data Pusat Sumber Daya Geologi (2016), Indonesia memiliki potensi sumber daya nikel sebesar 5.756.362.683 (bijih) dan 79.172.702 (logam) dan cadangan nikel sebesar 3.197.178.940 (bijih) dan 50.872.304 (logam) dengan kandungan unsur nikel ratarata $1,20 \%-3,25 \%$. Cadangan bijih nikel di Indonesia digolongkan kepada cadangan terbukti (proven) dan terkira (probable), sedangkan sumber daya bijih nikel digolongkan kepada sumber daya hipotetik, tereka, tertunjuk dan terukur (Tabel 5). Sebagian dari sumber daya dan cadangan nikel tersebut sudah ditambang dan diekspor dalam bentuk bijih nikel oleh perusahaan-perusahaan yang banyak bertumbuhan dalam dasawarsa terakhir. Seiring dengan meningkatnya permintaan produk logam dunia. Sebagian lagi diekspor dalam bentuk barang hasil olahan, seperti nickel matte (PT Vale Indonesia (Inco) dan ferro nickel (PT Aneka Tambang).

Sumber daya dan cadangan nikel ini dalam kurun waktu 2011-2015 terus meningkat disebabkan adanya penemuan sumber daya nikel yang baru. Pada tahun 2011 sumber daya nikel berjumlah sebesar 2,85 miliar ton, pada tahun 2012 meningkat cukup besar menjadi 3,34 miliar ton karena adanya produksi yang meningkat pesat namun juga adanya penemuan sumber daya nikel yang juga cukup besar mencapai 539,60 juta ton. Pada tahun 2013 sumber daya nikel meningkat kembali menjadi 3,56 miliar ton disebabkan adanya penemuan sumber daya baru yang mencapai 277,27 juta ton, dan pada tahun 2014 meningkat kembali menjadi 3,71 miliar ton karena adanya penemuan sumber daya baru sebesar 150,86 juta ton dan pada tahun 2015 sumber daya meningkat sangat besar sekali menjadi 5,65 miliar ton karena adanya penemuan sumber daya yang baru lagi sebesar 1,94 miliar ton (Gambar 2, Tabel 8 dan 9).

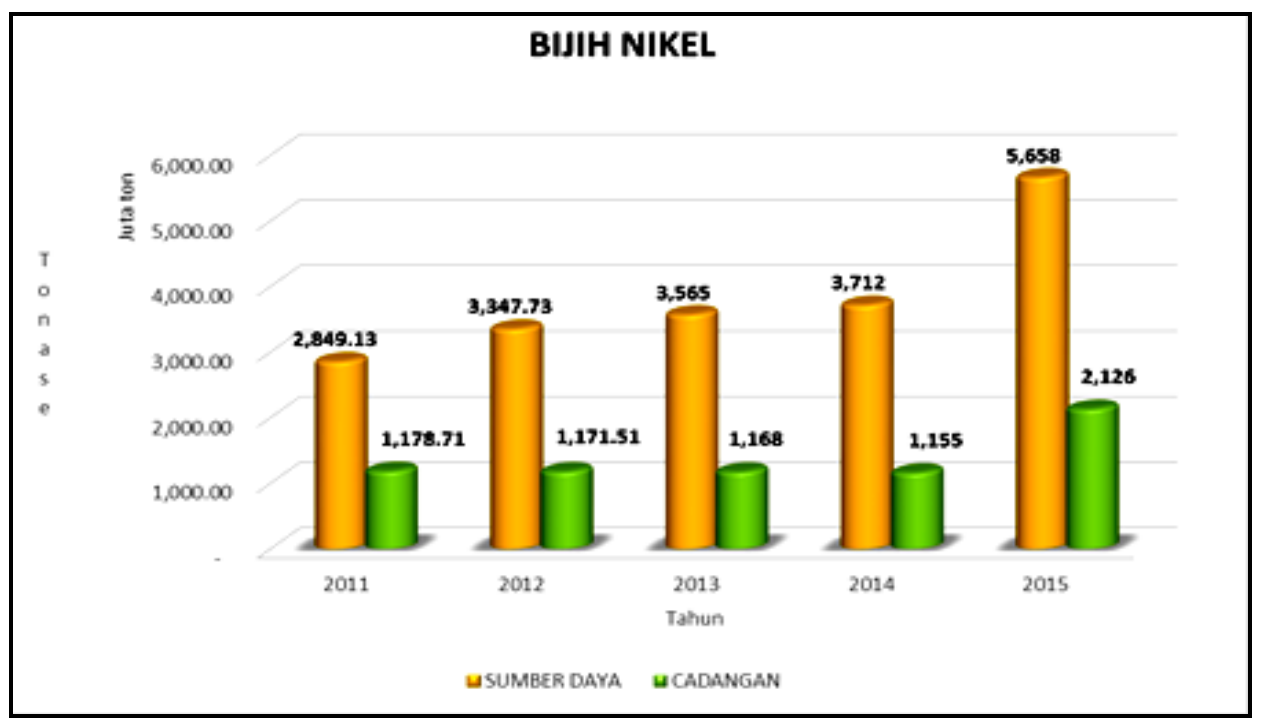

Sumber : Pusat Sumber Daya Geologi (2016).

Gambar 2. Total sumber daya nikel tahun 2011-2015 


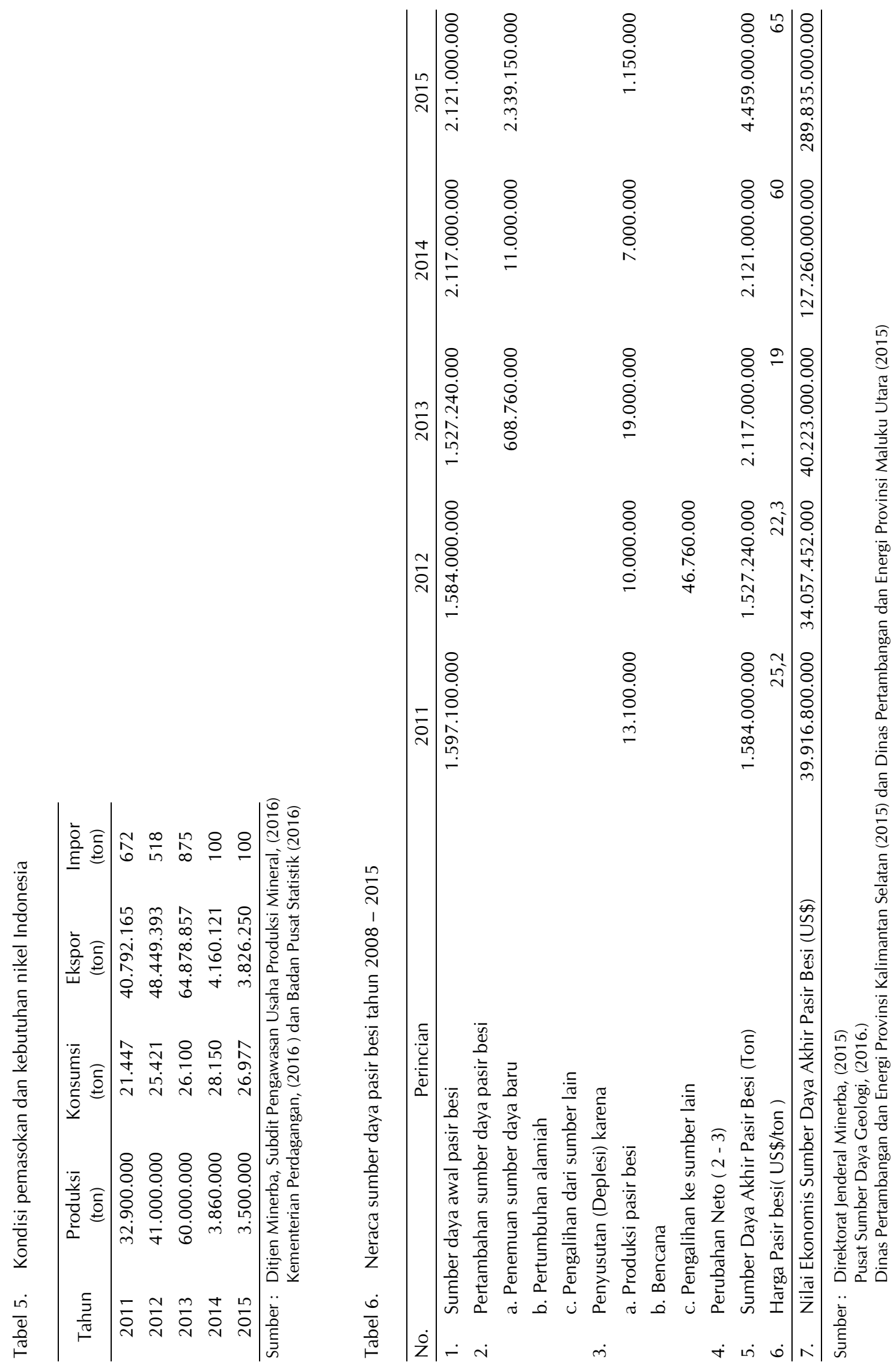




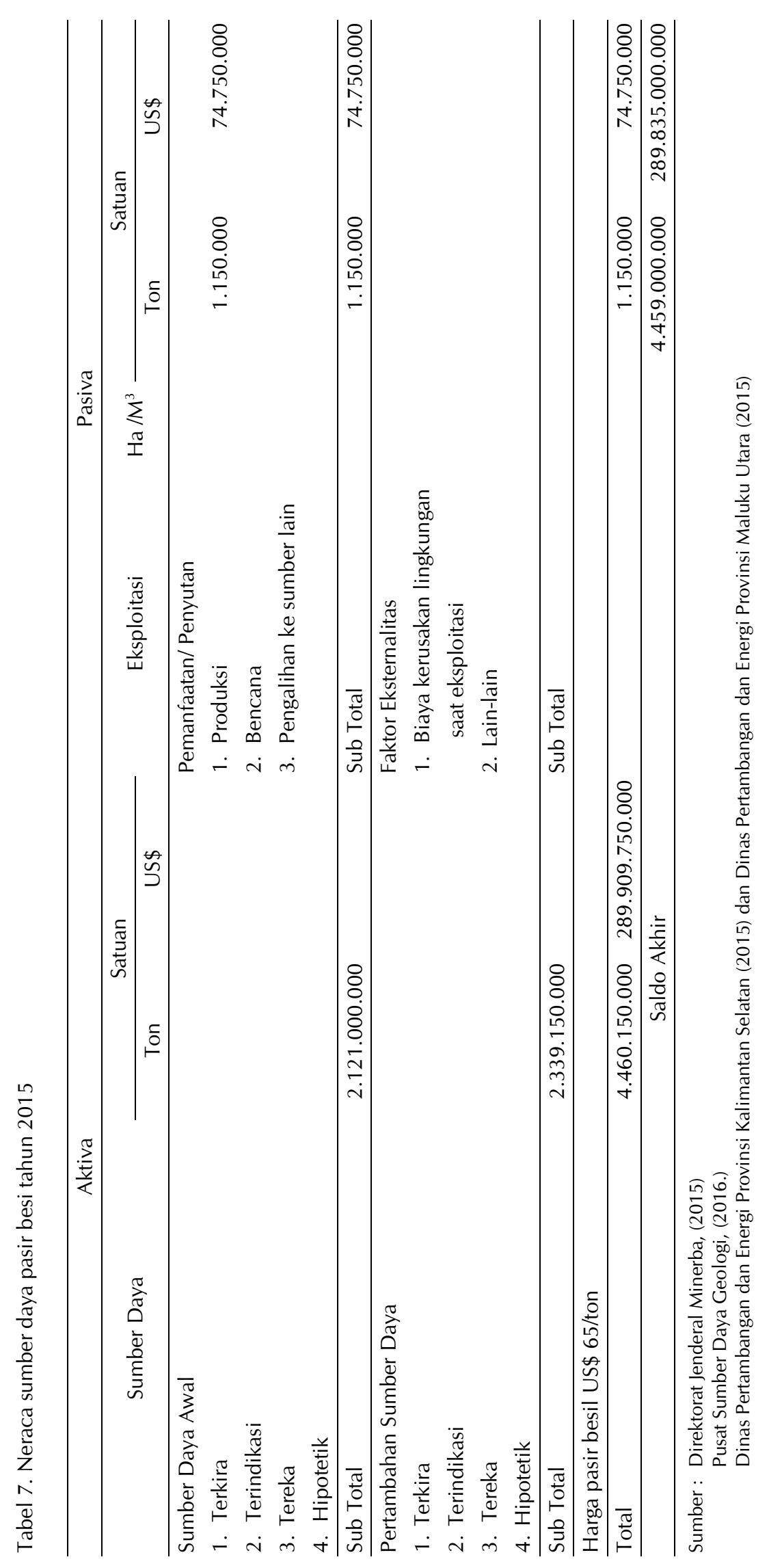




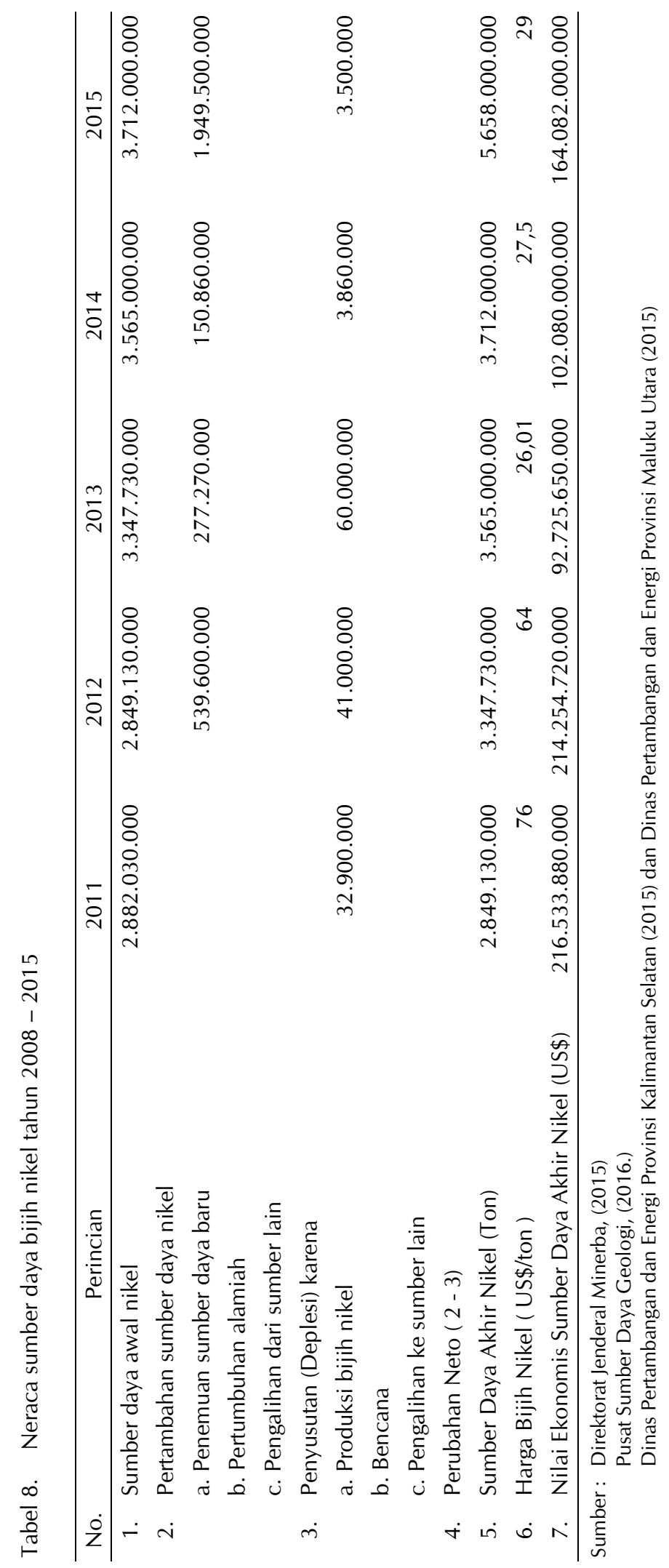




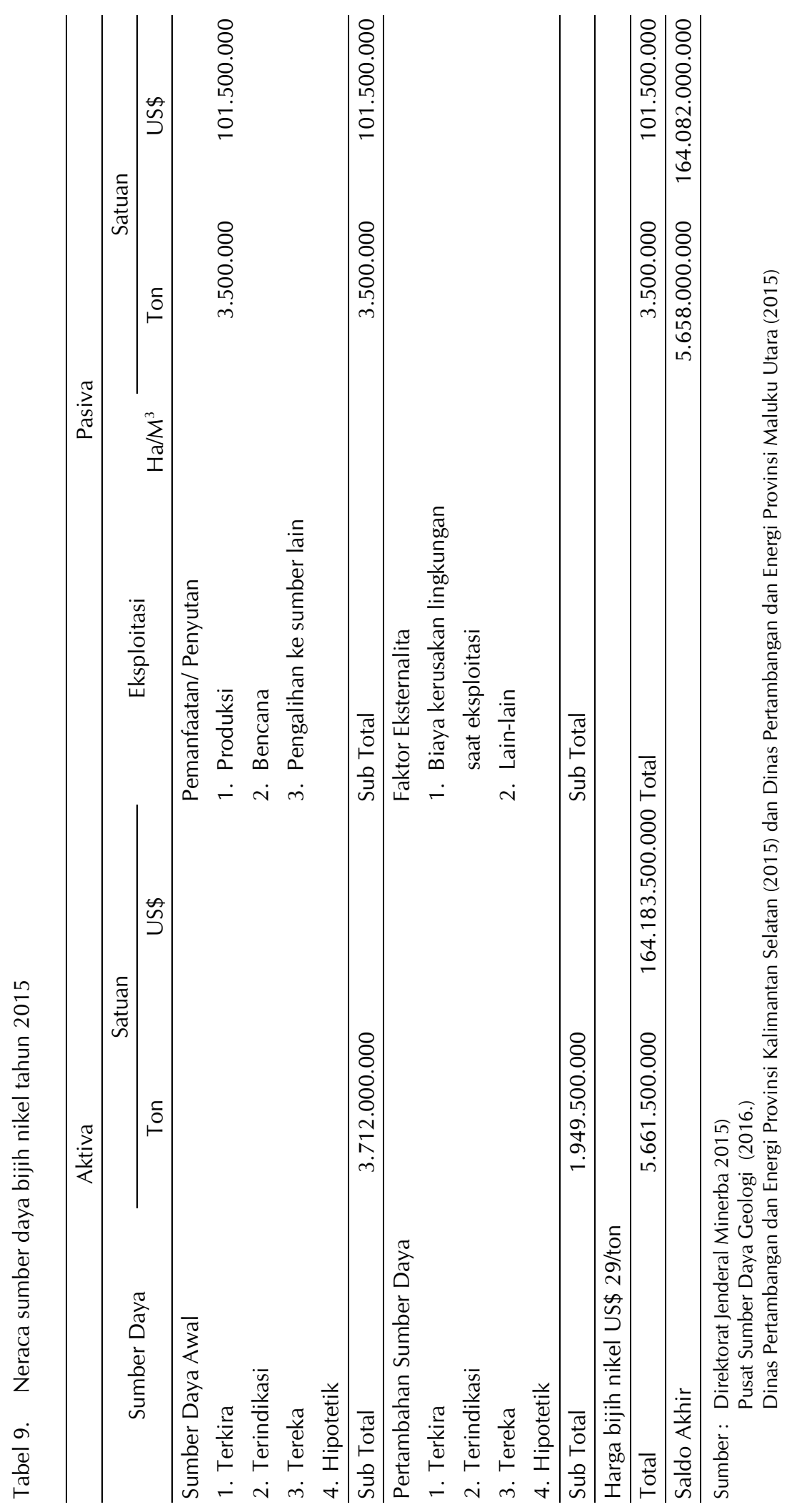


Jenis cadangan nikel di Indonesia terbagi dua menurut kadarnya yakni bijih nikel kadar rendah jenis limonitik dengan kandungan $\mathrm{Ni}$ rendah : $1,4-1,7 \%$ di samping mengandung Co relatif tinggi $(0,008-0,12 \%)$ dan besi tinggi. Jenis ini biasanya terdapat di Lapisan Atas tanah; dan bijih nikel kadar tinggi jenis saprolitik/garnertitik dengan kadar $\mathrm{Ni}$ : 1,8 2,7\%, Co: 0,03 - 0,08\% dan kadar besinya rendah (Distam Maluku Utara, 2015). Sementara ini, Indonesia mempunyai cadangan nikel laterit terindetifikasi sekitar 3,19 miliar ton dengan total kandungan nikel sebanyak 50,87 juta ton. Hal ini menjadikan Indonesia sebagai sumber nikel laterit terbesar ketiga dunia setelah Kaledonia Baru dan Filipina. Distribusi deposit laterit nikel Indonesia antara lain berada di Sulawesi (Lembo, Bahodopi, Kolonedale, Laroeni, Kandeapi, Sorowako, Patea, Sampala, Matarape, Lasolo, Tapunopaka, Mandiono, Bahubulu, Langgikima, Tambakua, Tolala, Sua-sua, Pao-pao, Maniang, Pomala, Sopura, Iwoikondo, Torobulu dan Matapulu), di Maluku (Wasile, Sangaji, Mornopo, Tanjung Buli, P. Gee, P. Gebe, P. Gag, P. Pakal, Bangul, Tofu Blewen, Bikep, Fonli, Ake Jira, Mesa, Kawasi dan Malamala), Kalimantan (Gunung Nuih) dan Papua (Topo, Siduarsi, Tanah Merah, Tablasufa, Amaybu, Kirpon dan Sentani).

Hingga kini terdapat dua perusahaan pertambangan nikel berskala besar yang beroperasi di Indonesia yaitu PT Aneka Tambang (Antam) di Pomalaa dan Maniang, Sulawesi Tenggara dan di Buli, Maluku Utara, sedangkan PT Vale Indonesia (Inco) beroperasi di Sorowako, Sulawesi Selatan. Selain kedua perusahaan itu, terdapat ratusan perusahaan tambang nikel yang beroperasi terutama di Sulawesi Tenggara.

PT Antam memproduksi dua jenis nikel yaitu bijih nikel dan feronikel, sedangkan PT Vale Indonesia (Inco) memproduksi converter matte dan $\mathrm{Ni}+\mathrm{Co}$ in matte. Sebagian besar produksi nikel Indonesia diekspor antara lain ke Jepang, Australia, dan Belanda. Sedangkan perusahaan tambang-tambang kecil mengekspor bijih nikel ke China. Seluruh sumber daya dan cadangan nikel Indonesia, tersebar di Kalimantan Timur, Sulawesi Tengah, Sulawesi Selatan, Sulawesi Tenggara, Maluku Utara, Papua Barat, Irian Jaya Barat dan Papua. Cadangan yang mungkin (possible) yang cukup besar baik di wilayah kerja PT Antam maupun di wilayah kerja PT Vale Indonesia (Inco), cukup untuk menunjang kegiatan kedua perusahaan ini untuk beberapa puluh tahun yang akan datang.

\section{Industri Pengguna Nikel}

Produksi nikel banyak digunakan oleh berbagai industri di antaranya, penggunaan secara langsung dalam bentuk nikel murni (Industri laboratorium fisika dan kimia; industri anoda untuk betere; industri radio, industri transistor).

Penggunaan secara tidak langsung dalam bentuk paduan logam nikel dan besi (Paduan logam kadar nikel 0,5-10\% untuk industri peralatan mesin berat, industri transportasi; Paduan logam kadar nikel 5-20\% untuk industri hul, plate, misil, permesinan; Paduan logam kadar nikel $0,5-20 \%$ untuk industri mesin-mesin berat, rel kereta api, pembuatan peralatan proses pencairan gas alam; Paduan logam kadar nikel 30-90\% untuk industri peralatan listrik, industri peralatan komunikasi; Paduan kadar nikel $14-28 \%$ untuk industri komponen motor, industri generator, dan industri instrumentasi; Paduan kadar nikel 4$90 \%$ untuk industri peralatan listrik, dan industri peralatan magnetik; Paduan kadar nikel $5-40 \%$ untuk industri pemroses makanan, industri kimia dan industri minyak bumi; Paduan kadar nikel $22-50 \%$ untuk industri instrumen per chronometer, industri elektronik).

Penggunaan secara tidak langsung (Paduan nikel bukan besi atau paduan nikel tembaga (Paduan nikel kromium dan paduan nikel alumunium). Paduan nikel kadar 2-45\% untuk industri kerangan pipa air; Paduan nikel kadar $30-70 \%$ untuk industri pelat dan tabung, industri kondensor, industri kimia, industri peralatan penukar panas; Paduan nikel kadar $25-75 \%$ untuk industri pembuatan mata uang logam; Paduan nikel kadar 30-75\% untuk industri peralatan pengolahan makanan, industri kimia, dan industri minyak bumi; Paduan nikel kadar $45-90 \%$ untuk industri peralatan listrik, industri telepon, industri kedokteran gigi, dan industri arsitektur; Paduan nikel kadar -26-60\% untuk industri konstruksi, industri industri kimia, industri value seatings, industri mesin pembakar 
internal; dan Paduan nikel kadar 20-80\% untuk industri pembuatan turbin blades pesawat terbang.

\section{Produksi Bijih Nikel}

Produksi bijih nikel Indonesia dalam kurun waktu 2011-2015 meningkat berfluktuasi. Pada tahun 2011 produksi bijih sebesar 32,90 juta ton, pada tahun 2013 produksi meningkat sangat besar menjadi 60,00 juta ton. Peningkatan tersebut ditunjang oleh PT Vale Indonesia (Inco) yang berusaha terus untuk meningkatkan kapasitas produksinya, serta produksi besarbesaran dari seluruh pemegang IUP, sebelum diberlakukannya larangan ekspor bijih nikel pada tahun 2014 yang merupakan amanat Undang-Undang No. 4 tahun 2009 tentang Mineral dan Batubara. Pada tahun 2014 setelah berlakunya UU tersebut, ekspor menurun sangat besar hingga mencapai 3,86 juta dan pada tahun 2015 menjadi 3,50 juta ton (Tabel 3).

Sebagian besar hasil tambang nikel di Indonesia hingga saat ini diekspor. Sedangkan untuk memenuhi kebutuhan nikel di dalam negeri terutama untuk industri hilirnya, selama ini diimpor nikel dalam bentuk logam. Logam Nikel yang dikonsumsi di dalam negeri tersebut biasanya berupa unwrought nickel, nickel bar and rod, nickel powder, nickel wire, nickel tubes and pipes, nickel foil. Nikel yang diimpor dalam bentuk bijih sangat sedikit, oleh sebab itu konsumsi nikel di dalam negeri hanya diperhitungkan dari besarnya konsumsi logam nikel tersebut.

\section{KESIMPULAN DAN SARAN}

\section{Kesimpulan}

Indonesia memiliki sumber daya serta cadangan pasir besi dan bijih nikel yang sangat besar. Namun, sampai saat ini besarnya sumber daya tersebut belum memberikan manfaat yang optimal bagi kesejahteraan nasional, karena pemerintah kesulitan membuat kebijakan yang tepat mengenai pengelolaan sumber daya terse-but yang dapat memberikan keuntungan bagi seluruh pemangku kepentingan.

Sulitnya pemerintah membuat kebijakan yang tepat mengenai pengelolaan sumber, disebabkan antara lain karena data dan informasi sumber daya, serta perkiraan dan analisis keekonomiannya secara periodik belum dimiliki, validasi data belum terdokumentasi dengan akurat, belum standar, dan belum terintegrasi, karena belum ada koordinasi dan sinkronisasi antar instansi terkait yang menangani data sumber daya, khususnya pasir besi dan nikel.

Hasil Analisis Neraca Sumber Daya Pasir Besi dan Nikel ini, antara lain bisa digunakan sebagai salah satu masukan /dasar bagi pemerintah pusat dan daerah serta lembaga terkait dalam perumusan kebijakan pada tataran masing-masing.

\section{Saran}

Agar neraca sumber daya pasir besi dan nikel ini benar-benar memberikan manfaat yang besar bagi seluruh pemangku kepentingan sebagaimana diuraikan dalam kesimpulan, maka disarankan :

- Data dan informasi sumber daya dibuat perkiraan keekonomiannya secara periodik dengan koordinasi dan sinkronisasi seluruh instansi terkait yang menangani data sumber daya, diantaranya, Dinas Pertambangan, Pusat Sumber Daya Geologi, BPS, Ditjen Mineral dan Batubara, Kementerian Perindustrian, Kementerian Perdagangan dan Pusat Data dan Teknologi Informasi Kementerian ESDM.

- Data mengenai sumber daya mineral dipusatkan pada Pusat Data dan Teknologi Informasi Kementerian ESDM, sehingga seluruh pemangku kepentingan, yang membutuhkan dapat memperoleh data yang seragam, terstandarisasi, terdokumentasi, akurat dan valid.

- Dibentuk Badan Geologi Nasional yang membawahi seluruh kementerian yang terkait dengan sumber daya, antara lain dengan Kementerian Pertanian, Kementerian Kelautan dan Perikanan, Kementerian Lingkungan Hidup dan Kehutanan serta Kementerian Energi dan Sumber Daya Mineral, sehingga tidak akan terjadi tumpang tindih lahan maupun tumpang tindih peraturan dan kebijakan yang terkait sumber daya (sumber daya lahan, sumber daya hutan, sumber daya air dan sumber daya mineral). 


\section{UCAPAN TERIMAKASIH}

Penulis mengucapkan terimakasih kepada lembaga dan institusi yang telah membantu memberikan data yang terkait dengan masalah neraca sumber daya mineral, antara lain Pusat Sumber daya Geologi, Badan Geologi Kementerian Energi dan Sumber Daya Mineral, Direktorat Jenderal Mineral dan Batubara, para pakar yang terkait dengan neraca sumber daya. Terimakasih juga ditujukan kepada Dinas Pertambangan dan Energi Provinsi Kalimantan Barat dan Provinsi Maluku Utara sebagai wilayah yang memiliki sumber daya pasir besi dan nikel yang besar. Terimakasih juga diberikan kepada Subdit Perencanaan Wilayah dan Informasi Mineral dan Batubara Direktorat Jenderal Mineral dan Batubara.

\section{DAFTAR PUSTAKA}

Anna, A. N., Priyono, K. D., Suharjo and Priyana, Y. (2016) “Neraca sumber daya air wilayah dan kekritisan air meteorologis daera aliran sungai Bengawan Solo Hulu," in The 3rd University Research Colloquium 2016. Surakarta: Konsorsium LPPM PTM/PTA, pp. 25-35.

Arief, R., Suhandi and Putra, C. (2011) "Penelitian bahan galian lain dan mineral ikutan pada wilayah pertambangan di Kabupaten Minahasa Utara Provinsi Sulawesi Utara," in Prosiding Hasil Kegiatan Pusat Sumber Daya Geologi Tahun 2011. Bandung: Pusat Sumber Daya Geologi, pp. 1-18.

Artha, E. U., Rahadi, B. and Suharto, B. (2014) "Evaluasi daya dukung lingkungan berbasis neraca air di Kota Batu," Jurnal Sumber Daya Alam dan Lingkungan, 1(3), pp. 49-54.

Badan Standardisasi Nasional (2015) “Petunjuk teknis penyusunan neraca spasial sumber daya alam bagian ke-4, neraca sumber daya dan cadangan mineral dan batubara." Indonesia: Standar Nasional Indonesia (SNI).

Dinas Pertambangan dan Energi Provinsi Kalimantan Selatan (2015) Publikasi pertambangan dan energi Provinsi Kalimantan Selatan. Banjarbaru.

Dinas Pertambangan dan Energi Provinsi Maluku Utara (2015) Publikasi pertambangan dan energi Provinsi Maluku Utara. Ternate.
Guswakhid, H. (2013) Kajian optimalisasi dan strategi sumber daya air di Kabupaten Rembang Jawa Tengah. Universitas Diponegoro.

Jacob, A. (2013) "Pengelolaan lahan alternatif untuk konservasi sumber daya air di daerah aliran sungai Batugantung Kota Ambon," Jurnal Agrogolia Ilmu Budidaya Tanaman, 2(1), pp. 25-35.

Jarwanto (2008) "Neraca sumber daya air Kota Banjarbaru, Kalimantan Selatan," Jurnalllmiah Magister Teknik Geologi, 1(1), pp. 10-24.

Jumari, Setiadi, D., Purwanto, Y. and Guhardja, E. (2013) "Pengelolaan sumber daya alam dan lingkungan dalam pandangan masyarakat Samin," in Hadi, S. P., Purwanto, Sunoko, H. R., and Purnawen, H. (eds.) Prosiding Seminar Nasional Pengelolaan Sumberdaya dan Lingkungan 2013. Semarang: Program Studi Magister dan Doktor Ilmu Lingkungan Universitas Diponogoro, pp. 64-70.

Muliawan, L., Reswati, E. and Munajati, S. L. (2009) "Neraca sumber daya kelautan dan perikanan sebagai landasan kebijakan dalam pengelolaan sumber daya kelautan dan perikanan," Majalah Ilmiah Globe, 11(1), pp. 18-30. doi: 10.24895/MIG.2009.11.

Nurfatriani, F. (2006) "Konsep nilai ekonomi total dan metode penilaian sumber daya hutan," Jurnal Penelitian Sosial dan Ekonomi Kehutanan, 3(1), pp. 1-16.

Prasadewo, M. L., Rauf, A. and Titisariwati, I. (2016) "Potensi serta neraca sumber daya dan cadangan batu andesit di Kabupaten Kulon Progo D.I. Yogyakarta," Jurnal Teknologi Pertambangan, 1(2), pp. 93-98.

Pusat Sumber Daya Geologi (2016) Laporan akhir pemutakhiran data dan neraca sumber daya mineral. Bandung.

Putra, A. M., Rahadi, B. and Susanawati, L. D. (2015) "Penentuan daya dukung lingkungan berbasis neraca lahan tahun 2013 di Kota Baru," Jurnal Sumber Daya Alam dan Lingkungan, 2(1), pp. 1-6.

Sallata, M. K. (2015) "Konservasi dan pengelolaan sumber daya air berdasarkan keberadaannya sebagai sumber daya alam," Info Teknis EBONI, 12(1), pp. 75-86.

Setiawan, eka wahyu, Sutanhaji, A. T. and Suharto, B. (2014) "Identifikasi potensi sumber air permukaan dengan menggunakan DEM (digital elevation model) di Kabupaten 
Lembata Provinsi Nusa Tenggara Timur," Jurnal Sumber Daya Alam dan Lingkungan, 1(2), pp. 41-50.

Soepriadi, Seraphine, N. and Novihapsari, D. M. (2013) "Potensi endapan pasir besi di Kabupaten Lampung Barat, Provinsi Lampung," Buletin Sumber Daya Geologi, 8(1), pp. 15-25.

Solihin, M. A. and Sudirja, R. (2007) "Pengelolaan sumber daya alam secara terpadu untuk memperkuat perekonomian lokal," SoilRens, 8(15), pp. 82-93.

Tivianto, T. A., Munajad, R. and Wijanarko, S. R. (2013) "Estimasi aktiva dan pasiva sumber daya air dengan model neraca air dan sistem informasi geospasial berbasis pendekatan fisiografi di Kabupaten Blora," Jurnal SPATIAL - Wahana Komunikasi dan Informasi Geografi, 12(2), pp. 1-4. 
